\title{
FEEDING HABITS OF THE MARBLED GOBY, POMATOSCHISTUS MARMORATUS (ACTINOPTERYGII: PERCIFORMES: GOBIIDAE), IN THE ÇANAKKALE STRAIT, NORTHERN AEGEAN SEA, TURKEY
}

\author{
Aytac ALTIN ${ }^{*}$, Ozcan OZEN ${ }^{2}$, Hakan AYYILDIZ ${ }^{1}$, and I. Burak DABAN ${ }^{2}$ \\ ${ }^{1}$ Fisheries Technology Department, Gökçeada School of Applied Sciences, \\ Çanakkale Onsekiz Mart University, Gökçeada, Çanakkale, Turkey \\ ${ }^{2}$ Faculty of Marine Science and Technology, \\ Çanakkale Onsekiz Mart University, Terzioğlu Kampüsü, Çanakkale, Turkey
}

\begin{abstract}
Altin A., Ozen O., Ayyildiz H., Daban I. B. 2015. Feeding habits of the marbled goby, Pomatoschistus marmoratus (Actinopterygii: Perciformes: Gobiidae), in the Çanakkale Strait, northern Aegean Sea, Turkey. Acta Ichthyol. Piscat. 45 (1): 95-100.
\end{abstract}

\begin{abstract}
Pomatoschistus marmoratus (Risso, 1810) is a small demersal fish and one of the dominant species inhabiting shallow waters of the Mediterranean. Information, however, on their feeding habits are still scarce. In this study, the stomach contents of $P$. marmoratus were investigated in order to determine feeding habits according to seasons and sizes. The fish were collected monthly from 3 stations between October 2008 and August 2009 , using a beach seine, from the shallow waters of the Çanakkale Strait, Turkey. A total of 383 P. marmoratus, ranging from 13 to $69 \mathrm{~mm} \mathrm{TL}$, were analysed. The most important prey items in the stomach contents were copepods and amphipods. The numerical abundance of each food item in the stomach contents varied significantly with season. The diet of juvenile P. marmoratus consisted mainly of copepods. The occurrence of largest prey items such as amphipods and bivalves appeared relatively higher in adults. However, no significant differences were found between the feeding habits of juveniles and adults.
\end{abstract}

Keywords: diet, dominant species, demersal fish, stomach contents, Aegean Sea

Shallow waters play an important role for fish communities and serve as nurseries, feeding grounds, or shelters (Dulčić et al. 2005). Many fish species use shallow waters in the juvenile stage of their lives (Macpherson and Duarte 1991). The genus Pomatoschistus comprises small epibenthic Atlantic-Mediterranean species, distributed along the shallow waters, especially in estuaries and lagoons (Tortonese 1975, Berrebi et al. 2005). Marbled goby, Pomatoschistus marmoratus (Risso, 1810), is one of the dominant fish species (Verdiell Cubedo et al. 2008, Koutrakis and Tsikliras 2009, Verdiell-Cubedo et al. 2012) and a potential competitor for the available food resources in the shallow waters of the Mediterranean (VerdiellCubedo et al. 2007).

The marbled goby is widespread in the eastern Atlantic (Iberian Peninsula), Mediterranean, Black Sea, Sea of Marmara (Demirel and Murat Dalkara 2012), Sea of Azov, and had also been introduced to the Suez Canal and to Lake Quarun, Egypt (Bauchot and Hureau 1986, Fouda et al. 1993). It is a small-bodied fish, reaching a maximum total length of $65 \mathrm{~mm}$, inhabiting sandy, inshore, shallow waters down to $20 \mathrm{~m}$ of depth (Bauchot and Hureau 1986). Malavasi et al. (2005) reported that the habitat choice of this species were sandy bottoms towards the sea grass beds, salt marsh creeks, and mud flats. The breeding season of Pomatoschistus marmoratus is extended and the egg size appears to correlate with both female and male size (Mazzoldi et al. 2002). Spawning of this species occurs between November and September in the Mediterranean and from March to mid-September in the Black Sea (Bauchot and Hureau 1986, Fouda et al. 1993, Koutrakis and Tsikliras 2009). The values of the first sexual maturity length of this species were reported between $2.4 \mathrm{~cm}$ and $4.8 \mathrm{~cm}$ in the Mediterranean (Koutrakis and Tsikliras 2009). Feeding habits of P. marmoratus in the Mediterranean has been poorly studied; only one study was conducted in the Suez Canal, Egypt (Fouda 1995).

The feeding habits of Pomatoschistus marmoratus, as a dominant species, are very important to understand trophic organizations of fish communities in shallow

\footnotetext{
* Correspondence: Dr. Aytaç Altın, Çanakkale Onsekiz Mart Üniversitesi, Gökçeada Uygulamalı Bilimler Yüksekokulu, Balıkçılık Teknolojisi Bölümü, 17760, Gökçeada, Çanakkale, Turkey, phone: +902868872303, fax: +902868872302, e-mail: (AA) aytacaltin@gmail.com, (OO) oozen@yahoo.com, (HA) h_ayyildiz17@hotmail.com, (IBD)burakdaban@gmail.com.
} 
waters. In this sense, the purpose of this study was to determine the feeding habits of $P$. marmoratus from shallow waters of the Çanakkale Strait. The collected specimens were also divided into two size groups (juveniles and adults) to determine the relation between the body size and the feeding habits. Seasonal variations of diet compositions were also investigated.

Three different stations were selected in the shallow waters $(<2 \mathrm{~m})$ of the Çanakkale Strait, Turkey (Fig. 1). The Çanakkale Strait is a part of the Turkish Straits System (TSS); it is $62 \mathrm{~km}$ long with a mean depth of $55 \mathrm{~m}$. This region is a migration route of many economically important fish species and exploited by many fishermen. Shallow waters of the Çanakkale Strait not only a biological corridor but also an invaluable feeding and sheltering area for recruitment of the many fish species.

Samples were collected monthly, between October 2008 and August 2009, with a beach seine with a total wing length of $32 \mathrm{~m}$, a height of $2 \mathrm{~m}, 2-\mathrm{m}$ long bag with 13-mm stretched mesh size at wing, and $5 \mathrm{~mm}$ stretched mesh at bag. Beach seine operations were carried out according to instructions described by Able et al. (2003) and Wilber et al. (2003).

Fish were killed with an overdose of quinaldine and stored in 4\% formaldehyde. The fish-species identification was aided by Bauchot and Hureau (1986). Total lengths (TL) of fish were measured to the nearest $1 \mathrm{~mm}$. Stomach of samples were taken out and stored into $70 \%$ alcohol solution. Stomach contents were identified to the possible lowest taxonomic level (Hayward and Ryland 1995) and then counted.

Diet was analyzed using two standard indices: the Frequency of occurrence* and the Numerical abundance\# (modified from Hyslop 1980). The percentage of stomachs containing prey item $i$-in relation to the total number of individuals excluding empty digestive tracts - was expressed as the Frequency of occurrence, while the numerical percentage of prey item $i$ among all prey items found-as the Numerical abundance. The Frequency of



Fig. 1. Sampling stations: $1=$ Abide, $2=$ Güzelyalı, $3=$ Kerevizdere occurrence $(F)$ and the Numerical abundance $(N)$ were calculated using the following formulas:

$$
\begin{aligned}
& F=\frac{n}{N_{s}} \times 100 \\
& N=\frac{n_{i}}{N_{p}} \times 100
\end{aligned}
$$

where $n$ is the number of stomachs containing items of a prey $i, N_{s}$ is the total number of non-empty stomachs, $n_{i}$ is the total number of individuals of a prey $i$, and $N p$ is the total number of all prey items. Also, vacuity index of fishes were calculated according to seasons and sizes.

In order to analyse seasonal and intraspecific differences in diet, the months were categorized into seasons (winter representing December, January, and February; spring representing March, April, and May; summer representing June, July, and August; and autumn representing October and November) and the fish specimens were divided into two size groups: small individuals (juvenile) (TL $<38$ $\mathrm{mm}$ ) and large individuals (adult) (TL $>38 \mathrm{~mm}$ ) (Koutrakis and Tsikliras 2009). In order to assess species richness and abundance in the stomach contents, Shannon-Weaver-, Dominance-, and Simpson diversity indices were calculated (Shannon 1948). Chi-square test $\left(\chi^{2}\right)$ was applied to determine vacuity index changes according to seasons. ANOSIM and SIMPER statistical analyses were used in order to determine similarities between seasonal feeding habits and also between size classes. All statistical analyses were performed with PAST version 3.04 package program (Hammer et al. 2001). Statistical significance level was set at $(\alpha) 0.05$.

A total of 1273 Pomatoschistus marmoratus were collected from the Çanakkale Strait. Out of this number, 383 P. marmoratus specimens (30\% of the total catch), ranging from 1.3 to $6.9 \mathrm{~cm} \mathrm{TL}$, were processed for stomach content analysis as a sub-sample. The sub-samples were selected randomly from each individual sample. A total of 167 stomachs were empty. The total vacuity index was calculated as: $21.3 \%$ in autumn, $63.1 \%$ in winter, $56.6 \%$

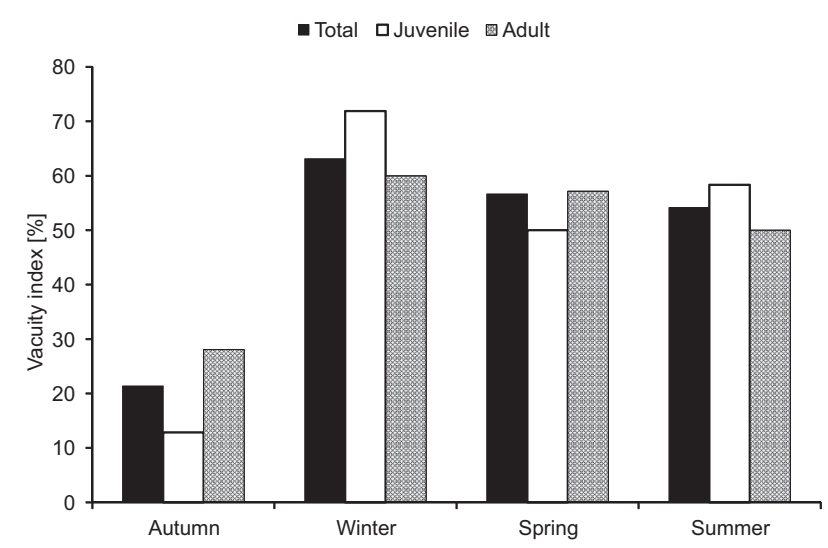

Fig. 2. Seasonal variations of the vacuity index of juvenile and adult individuals of marbled goby, Pomatoschistus marmoratus from the Çanakkale Strait, Turkey

\footnotetext{
* "\% $F$ " according to Cortés (1997).

\# “\% $N$ ” according to Cortés (1997).
} 
in spring, and $54.2 \%$ in summer. Although empty stomachs were found throughout the year, the Chi-square test did not show any significant differences between seasonal changes of vacuity index both juvenile and adults $\left(\chi^{2}=6.22, P>0.05\right)$ (Fig. 2).

The diet of Pomatoschistus marmoratus consisted of 21 different prey items, representing six major groups (Crustacea, Annelida, Mollusca, Nematoda, Foraminifera, and Algae). Crustaceans were the most important prey group, constituting $67.15 \%$ of the total number of prey items. Among crustaceans, the copepods were the most common prey in the diet $F=67.13 \%$ and $N=53.02 \%$ ), followed by the amphipods. The frequency of occurrence of Isopoda, Bivalvia, and Polychaeta were comparatively low in the diet (Table 1).

The diet of juvenile $P$. marmoratus consisted mainly of copepods $\left(N_{\%}=60.90 \%\right)$, amphipods $(N=5.40 \%)$, and isopods $(N=1.65 \%)$. The adults fed mainly on copepods $(N=42.62 \%)$, followed by amphipods $(N=12.71 \%)$, isopods $(N=1.82 \%)$, and bivalves $(N=1.69 \%)$. Copepod consumption was relatively important in juvenile individ- uals than the adults. The occurrence of largest prey such as amphipods and bivalve appeared relatively higher in relation to adults (Table 1). The species richness in the examined stomach contents increased considerably in adults. Moreover, the Dominance index was higher in juveniles (0.66) than in adults (0.38) (Table 2). However, no significant differences were found between the feeding habits of juveniles and adults (ANOSIM; Global $R$ statistic $=0.014 ; P>0.05)$.

Copepods were the most important prey group in summer $(N=88.2 \%)$ and in autumn $(N=51.43 \%)$. In addition, only three prey groups (copepods, amphipods $N=8.7 \%$, and algae $N=3.11 \%$ ) were observed in summer. The Shannon-Weaver index assumed the lowest value (0.43), while the Dominance index reached the highest value (0.78) in the same season. Amphipoda dominated the diet in winter $(N=35.2 \%)$ and spring $(N=47.1 \%)$ and in addition to, bivalve and isopod species they were observed relatively frequent in the stomach contents in these seasons (Fig. 3). Species richness in the examined stomach reached the highest level (21 species)

Frequency of individual prey items of marbled goby, Pomatoschistus marmoratus

Table 1 from the Çanakkale Strait, Turkey

\begin{tabular}{|c|c|c|c|c|c|c|c|}
\hline \multirow{3}{*}{ Taxon } & \multirow{3}{*}{ Prey item } & \multicolumn{6}{|c|}{ Index [\%] } \\
\hline & & \multicolumn{2}{|c|}{ General } & \multicolumn{2}{|c|}{ Juvenile } & \multicolumn{2}{|c|}{ Adult } \\
\hline & & $N$ & $F$ & $N$ & $F$ & $N$ & $F$ \\
\hline \multirow[t]{13}{*}{ Crustacea } & Amphipoda ALL & 8.55 & 34.26 & 5.4 & 26.74 & 12.71 & 69.86 \\
\hline & Gammaridae & 0.21 & 1.85 & 0.09 & 1.16 & 0.36 & 4.11 \\
\hline & Caprellida & 0.05 & 0.46 & & & 0.12 & 1.37 \\
\hline & Isopoda & 1.72 & 8.33 & 1.65 & 9.3 & 1.82 & 13.7 \\
\hline & Mysidae & 0.26 & 0.93 & & & 0.61 & 2.74 \\
\hline & Cumacea & 0.16 & 0.93 & 0.18 & 1.16 & 0.12 & 1.37 \\
\hline & Tanaidacea & 0.36 & 2.78 & 0.09 & 1.16 & 0.73 & 6.85 \\
\hline & Peracarida UI & 0.1 & 0.93 & & & 0.24 & 2.74 \\
\hline & Copepoda ALL & 53.02 & 67.13 & 60.9 & 83.72 & 42.62 & 100 \\
\hline & Harpacticoida & 0.78 & 1.39 & 1.01 & 2.33 & 0.48 & 1.37 \\
\hline & Decapoda UI & 1.04 & 4.17 & 0.46 & 4.65 & 1.82 & 6.85 \\
\hline & Dendrobranchiata & 0.05 & 0.46 & 0.09 & 1.16 & & \\
\hline & Crustacea UI & 0.83 & 3.24 & 0.82 & 3.49 & 0.85 & 5.48 \\
\hline Annelida & Polychaeta & 0.83 & 4.17 & 0.55 & 4.65 & 1.21 & 6.85 \\
\hline \multirow[t]{3}{*}{ Mollusca } & Bivalvia & 0.89 & 6.48 & 0.27 & 3.49 & 1.69 & 15.07 \\
\hline & Gastrapoda & 0.57 & 3.24 & 0.09 & 1.16 & 1.21 & 8.22 \\
\hline & Mesogastrapoda & 0.1 & 0.93 & & & 0.24 & 2.74 \\
\hline Nematoda & & 0.68 & 4.17 & 0.18 & 2.33 & 0.48 & 5.48 \\
\hline Foraminifera & & 0.73 & 6.48 & 0.64 & 8.14 & 0.85 & 9.59 \\
\hline Algae & & 0.26 & 0.46 & & & 0.61 & 1.37 \\
\hline Digested & & 3.13 & 7.41 & 2.47 & 9.3 & 4 & 10.96 \\
\hline Sand & & 25.81 & 5.56 & 24.73 & 8.14 & 27.24 & 6.85 \\
\hline Unidentified & & 0.21 & 0.46 & 0.37 & 1.16 & & \\
\hline
\end{tabular}

$N=$ numerical abundance, $F=$ frequency of occurrence, $\mathrm{UI}=$ unidentified. 
in autumn, whereas, the Shannon-Weaver index (1.77) peaked in winter (Table 2). The ANOSIM analysis showed significant differences between seasons for feeding habits of Pomatoschistus marmoratus $(R=0.1438$; $P<0.05)$. SIMPER analysis showed that seasonal variety of feeding habits of the species were composed of Copepoda (Contribution $=53.73 \%$ ), Amphipoda $($ Contribution $=19.24 \%)$, Isopoda $($ Contribution $=3.45 \%)$, and Bivalvia (Contribution $=2.82 \%$ ) species (Table 3 ).

The marbled goby is a small-bodied fish and described as bottom- and opportunist feeder (Miller 1979, Fouda 1995). The findings of this study are generally consistent with those of Fouda (1995) who found that the species fed mostly on harpacticoid copepod, polychaetes, demersal eggs in the Suez Canal. There are some differences, however; For example, Fouda (1995) reported that the copepods were the most important prey group in winter and spring. In the presently reported study, however, we determined that the food of Pomatoschistus marmoratus consisted almost exclusively of copepods in the summer. It is well known that food availability is one of the most important parameters due to its effect on feeding habits of fish species (Wassef and Eisawy 1985). According to the Büyükateș and İnanmaz (2010) copepod species were present throughout the whole year and they dominated both surface- and mixed layer of water in the Çanakkale
Strait. Furthermore, the above-mentioned authors observed also two peaks in the zooplankton abundance; the first was in early spring and the second was in midsummer. In addition, Fouda (1995) stated that polychaetes peaked in winter while the amounts of Amphipoda in the stomach content were nearly constant in all seasons. In contrast to this, we observed very few polychaetes during the investigation and, peracarid species (Amphipoda and Isopoda) were the most important prey group in winter and spring in stomach contents of $P$. marmoratus. Similarly, Aslan-Cihangir and Pancucci-Papadopoulou (2011) reported that, the occurrence of peracarid species in the Çanakkale Strait increased from winter to summer and decreased in autumn. On the other hand, Fouda (1995) determined that, $P$. marmoratus more frequently consumed them than the other food items (replacing dominant polychaetes and copepods) during the autumn. The results of this study demonstrated that the amounts of amphipods and copepods tended to decrease and the species richness and the abundance in the stomach contents attained maximum values in autumn. Additionally, the vacuity index was the lowest for both juveniles and adults in the same season.

Morphology is one of the most important factors affecting the feeding strategy of many fish species. The juvenile individuals have small jaws and they tend to

Table 2

Seasonal variations in selected biodiversity indices of food items in the stomach contents of juvenile and adult individuals of marbled goby, Pomatoschistus marmoratus from the Çanakkale Strait, Turkey

\begin{tabular}{lcccccc}
\hline \multirow{2}{*}{ Index } & \multirow{2}{*}{ Juvenile } & Adult & \multicolumn{4}{c}{ Season } \\
\cline { 5 - 8 } & & & Spring & Winter & Autumn & Summer \\
\hline Taxa_S & 18 & 21 & 6 & 10 & 21 & 3 \\
Individuals & 822 & 601 & 31 & 112 & 1119 & 161 \\
Dominance (D) & 0.6617 & 0.3795 & 0.3236 & 0.2323 & 0.5616 & 0.7864 \\
Simpson (1-D) & 0.3383 & 0.6205 & 0.6764 & 0.7677 & 0.4384 & 0.2136 \\
Shannon (H) & 0.8811 & 1.571 & 1.348 & 1.769 & 1.145 & 0.431 \\
\hline
\end{tabular}

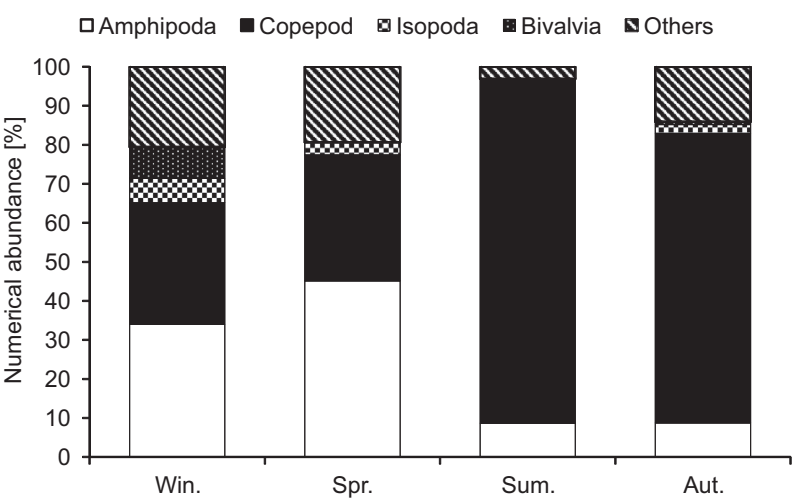

Fig. 3. Seasonal feeding habits of marbled goby, Pomatoschistus marmoratus from the Çanakkale Strait, Turkey; Win. = winter, Spr. = spring, Sum. = summer, Aut. = autumn
Table 3

Seasonal differences in individual feed groups of marbled goby,

Pomatoschistus marmoratus from the Çanakkale Strait, Turkey based on SIMPER analysis

\begin{tabular}{lcc}
\hline Taxon & $\begin{array}{c}\text { Average } \\
\text { dissimilarity }\end{array}$ & Contribution [\%] \\
\hline Copepoda & 41.99 & 53.73 \\
Amphipoda & 15.04 & 19.24 \\
Digested & 4.901 & 6.27 \\
Isopoda & 2.702 & 3.457 \\
Bivalvia & 2.203 & 2.818 \\
Foraminifera & 1.544 & 1.975 \\
Polychaeta & 1.434 & 1.835 \\
\hline
\end{tabular}


ingest small food items and they consume minimum energy to access food resources in the settlement period (Costa and Cataudella 2007). The increase in the fish size is accompanied by an increase in the consumed prey size. Fouda (1995) reported that consumption of harpacticoid copepods decreased parallel to increasing of the fish size and polychaetes became more important prey items for the larger individuals. In this study, stomachs of juvenile fish contained more copepods and fewer amphipods compared to adults. There were no significant differences, however, between juvenile and adult individuals in terms of their feeding habits.

In the northern Aegean, Pomatoschistus marmoratus has been reported as one of the dominant fish species (Koutrakis et al. 2005). Similarly, this species has been found as dominant in the shallow waters of the Çanakkale Strait by the present authors (unpublished data). The results of this study indicate that $P$. marmoratus shares the same preys such as copepods and amphipods, with many economically important juvenile fish species in the study area (Altın et al. 2015). In this respect, this species can play an important role in trophic structure of the shallow waters. Further research should be done to investigate the trophic structure and competition of this species.

\section{ACKNOWLEDGEMENTS}

This study was funded by The Scientific and Technological Research Council of Turkey (TÜBİTAK project number: 108T624). We are especially indebted to Alkan Öztekin. and Cahit Ceviz for logistical support in the field and to Abdullah Suat Ateş, Murat Sezgin, and Özgür Emek Inanmaz for their help in the laboratory.

\section{REFERENCES}

Able K.W., Rowe P., Burlas M., Byrne D. 2003. Use of ocean and estuarine habitats by young-of-year bluefish (Pomatomus saltatrix) in the New York Bight. Fishery Bulletin 101 (2): 201-214.

Altın A., Özen Ö., Ayyıldız H., Ayaz A. 2015. Feeding habits and diet overlap of juveniles of two sparids, Diplodus puntazzo (Walbaum, 1792) and Diplodus vulgaris (Geoffroy Saint-Hilaire, 1817), from north Aegean Sea of Turkey. Turkish Journal of Zoology 39 (1): 80-87.

DOI: 10.3906/zoo-1312-2

Aslan-Cihangir H., Pancucci-Papadopoulou M.A. 2011. Spatial and temporal variation of soft-bottom peracarid (Crustacea: Peracarida) infauna in the Canakkale Strait (Turkey). Mediterranean Marine Science 12 (1): 153-182. DOI: $10.12681 / \mathrm{mms} .58$

Bauchot M.-L., Hureau J.-C. 1986. Gobiidae. Pp. 1019-1085. In: Whitehead P.J.P., Bauchot M.-L., Hureau J.-C., Nielsen J., Tortonese E. (eds.) Fishes of the North-eastern Atlantic and the Mediterranean Vol. 3. UNESCO, Paris.

Berg J. 1979. Discussion of methods of investigating the food of fishes, with reference to a preliminary study of the prey of Gobiusculus flavescens (Gobiidae). Marine Biology 50 (3): 263-273.

DOI: $10.1007 / \mathrm{BF} 00394208$
Berrebi P., Rodriguez P., Tomasini J.-A., Cattaneo-Berrebi G., Crivelli A.J. 2005. Differential distribution of the two cryptic species, Pomatoschistus microps and P. marmoratus, in the lagoons of southern France, with an emphasis on the genetic organisation of $P$. microps. Estuarine Coastal and Shelf Science 65 (4): 708-716.

DOI: 10.1016/j.ecss.2005.07.008

Büyükateş Y., İnanmaz Ö.E. 2010. The annual mesozooplankton dynamics and influence of environmental parameters in an urbanized harbor (Kepez Harbor-Dardanelles Strait, Turkey). Ekoloji 19 (74): 60-68.

Cortés E. 1997. A critical review of methods of studying fish feeding based on analysis of stomach contents: Application to elasmobranch fishes. Canadian Journal of Fisheries and Aquatic Sciences 54 (3): 726-738.

DOI: $10.1139 /$ f96-316

Costa C., Cataudella S. 2007. Relationship between shape and trophic ecology of selected species of sparids of the Caprolace coastal lagoon (central Tyrrhenian Sea). Environmental Biology of Fishes 78 (2): 115-123. DOI: $10.1007 / \mathrm{s} 10641-006-9081-9$

Demirel N., Murat Dalkara E. 2012. Weight-length relationships of 28 fish species in the Sea of Marmara. Turkish Journal of Zoology 36 (6): 785-791.

DOI: $10.3906 /$ zoo-1111-29

Dulčić J., Matić-Skoko S., Kraljević M., Fencil M., Glamuzina B. 2005. Seasonality of a fish assemblage in shallow waters of Duće-Glava, eastern middle Adriatic. Cybium 29 (1): 57-63.

Fouda M.M. 1995. Life-history strategies of four small-size fishes in the Suez Canal, Egypt. Journal of Fish Biology 46 (4): 687-702. DOI: 10.1111/j.1095-8649.1995.tb01104.x

Fouda M.M., Hanna M.Y., Fouda F.M. 1993. Reproductive biology of a Red Sea goby, Silhouettea aegyptia, and a Mediterranean goby, Pomatoschistus marmoratus, in Lake Timsah, Suez Canal. Journal of Fish Biology 43 (1): 139-151. DOI: 10.1006/jfbi.1993.1116

Hammer Ø., Harper D.A.T., Ryan P.D. 2001. PAST: Paleontological Statistics Software package for education and data analysis. Palaeontologia Electronica 4 (1): [no consecutive pagination.]

Hayward P.J., Ryland J.S. (eds.) 1995. Handbook of the marine fauna of north-west Europe. Oxford University Press, Oxford, UK.

Hyslop E.J. 1980. Stomach contents analysis - a review of methods and their application. Journal of Fish Biology 17 (4): 411-429. DOI: $10.1111 / j .1095-8649.1980 . t b 02775 . x$

Koutrakis E.T., Tsikliras A.C. 2009. Reproductive biology of the marbled goby, Pomatoschistus marmoratus (Pisces, Gobiidae), in a northern Aegean estuarine system (Greece). Folia Zoologica 58 (4): 447-456.

Koutrakis E.T., Tsikliras A.C., Sinis A.I. 2005. Temporal variability of the ichthyofauna in a northern Aegean coastal lagoon (Greece). Influence of environmental factors. Hydrobiologia 543 (1): 245-257.

DOI: $10.1007 / \mathrm{s} 10750-004-7891-3$

Macpherson E., Duarte C.M. 1991. Bathymetric trends in demersal fish size: Is there a general relationship?. Marine Ecology Progress Series 71: 103-112. 
Malavasi S., Franco A., Fiorin R., Franzoi P., Torricelli P., Verdiell-Cubedo D., Oliva-Paterna F.J., Torralva M. 2007.

Mainardi D. 2005. The shallow water gobiid assemblage of the Venice Lagoon: abundance, seasonal variation and habitat partitioning. Journal of Fish Biology 67: 146-165.

DOI: $10.1111 / \mathrm{j} .0022-1112.2005 .00919 . x$

Mazzoldi C., Poltronieri C., Rasotto M.B. 2002. Egg size variability and mating system in the marbled goby Pomatoschistus marmoratus (Pisces: Gobiidae). Marine Ecology Progress Series 233: 231-239. DOI: $10.3354 / \mathrm{meps} 233231$

Miller P.J. 1979. Adaptiveness and implications of small size in teleosts. Symposia of the Zoological Society of London 44: 263-306.

Shannon C.E. 1948. A mathematical theory of communication. The Bell System Technical Journal 27 (3): 379-423. DOI: $10.1002 / j .1538-7305.1948 . t b 01338 . x$

Tortonese E. 1975. Osteichthyes: pesci ossei. [Osteichthyes: bony fishes.] Calderini, Bologna, Italy. [In Italian.]

Verdiell Cubedo D., Oliva Paterna F.J., Egea Serrano A., Torralva Forero M. 2008. Population biology and habitat associations of benthic fish species in the shallow areas of a Mediterranean coastal lagoon (SE Iberian Peninsula). Scientia Marina 72 (2): 319-328.

DOI: $10.3989 /$ scimar.2008.72n2319
The effects of competitors on fitness of marbled goby Pomatoschistus marmoratus (Pisces, Gobiidae) in the Mar Menor coastal lagoon (SE Iberian Peninsula). Italian Journal of Zoology 74 (2): 169-177.

DOI: $10.1080 / 11250000701202081$

Verdiell-Cubedo D., Torralva M., Andreu-Soler A., OlivaPaterna F.J. 2012. Effects of shoreline urban modification on habitat structure and fish community in littoral areas of a Mediterranean coastal lagoon (Mar Menor, Spain). Wetlands 32 (4): 631-641. DOI: $10.1007 / \mathrm{s} 13157-012-0296-6$

Wassef E., Eisawy A. 1985. Food and feeding habits of wild and reared gilthead bream Sparus aurata. Cybium 9 (3): 233-242.

Wilber D.H., Clarke D.G., Burlas M.H., Ruben H., Will R.J. 2003. Spatial and temporal variability in surf zone fish assemblages on the coast of northern New Jersey. Estuarine Coastal and Shelf Science 56 (2): 291-304.

DOI: 10.1016/S0272-7714(02)00163-4

Received: 20 May 2014

Accepted: 10 March 2015

Published electronically: 31 March 2015 